\title{
The Effects of Temperature, pH, and Bactericides on the Growth of Erwinia pyrifoliae and Erwinia amylovora
}

\author{
Rosemary Shrestha', Seon Hwa Lee ${ }^{2}$, Jang Hyun Hur ${ }^{1}$ and Chun Keun Lim ${ }^{1 *}$ \\ 'Division of Bio-Resources Technology and 'Division of Biological Environment, Kangwon National University, Chuncheon 200- \\ 701, Korea \\ (Received on February 1, 2005; Accepted on February 19, 2005)
}

In this comparative study, the effects of temperature, $\mathrm{pH}$, and bactericides on the growth of Erwinia pyrifoliae and Erwinia amylovora were investigated. The maximum temperature for the growth of both Erwinia species was estimated to be $36^{\circ} \mathrm{C}$. The maximum specific growth rates of $E$. pyrifoliae and $E$. amylovora were observed at $27^{\circ} \mathrm{C}$ and $28^{\circ} \mathrm{C}$, respectively, and no significant growth differences were shown at their optimum temperatures. However, at lower temperatures ranging from $12-21^{\circ} \mathrm{C}$, $E$. pyrifoliae showed higher growth rates with doubling times shorter than those of $E$. amylovora. Distinct growth rates at these temperatures revealed that $E$. pyrifoliae is more cold-tolerant than $E$. amylovora. The optimum pH for the growth of both pathogens was 7.5 and growth was not seen at $\mathrm{pH} \leq 5.0$ and $\geq \mathbf{1 0 . 0}$. These results showed that the effect of $\mathrm{pH}$ on the growth of $E$. pyrifoliae and $E$. amylovora was similar. Minimum inhibitory concentrations (MICs) of copper sulfate, oxolinic acid, streptomycin, and tetracycline, which inhibited growth of $E$. pyrifoliae and $E$. amylovora, were determined. The strains of both pathogens were able to grow at $0.08-0.32 \mathrm{mM}$ copper sulfate, but not at higher concentrations. However, none of the tested strains grew in the presence of oxolinic acid $(0.001 \mathrm{mM})$, streptomycin $(0.1 \mathrm{mM})$, and tetracycline $(0.01 \mathrm{mM})$ concentrations. These results suggested that all strains of both Erwinia species were sensitive to tested bactericides and indicated no occurrence of resistant strains of $E$. pyrifoliae in Korea.

Keywords : doubling time, $h r p N_{E p}$, minimum inhibitory growth, Pyrus pyrifolia, shoot blight

Erwinia pyrifoliae, a causal pathogen of shoot blight disease of the Asian pear (Pyrus pyrifolia cv. Singo), was isolated in Chuncheon, Korea (Rhim et al., 1999; Shrestha et al., 2003). The disease symptoms of shoot blight are similar to those of fire blight and bacterial shoot blight of pear (BSBP), which are caused by Erwinia amylovora and

\footnotetext{
*Corresponding author.

Phone) +82-33-250-6437, FAX) +82-33-256-8254

E-mail) chunkeun@kangwon.ac.kr
}

a Japanese Erwinia species, respectively (Beer et al., 1996; Kim et al., 2001; Mizuno et al., 2000). The morphological, cultural, and biochemical characteristics of $E$. pyrifoliae were also similar to those of Erwinia amylovora and a Japanese Erwinia sp. (Kim et al., 1999; Shrestha et al., 2003). However, molecular studies, including total DNADNA relatedness, sequence analysis of the $16 \mathrm{~S}-23 \mathrm{~S}$ rRNA intergenic transcribed spacer (ITS) region, and plasmid profiles, revealed that these three Erwinia species are genetically dissimilar (Jock et al. 2003; Maxson-Stein et al. 2003).

The effects of temperature and $\mathrm{pH}$ on growth have been studied in several phytopathogenic bacteria, including $E$. amylovora (Ark, 1937; Billing et al., 1961; Billing, 1974), Pseudomonas syringae, and Xanthomonas pruni (Young and Luketina, 1977). These effects had not yet been examined in E. pyrifoliae. To date, E. pyrifoliae has not been reported in other parts of the world, which suggests that this pathogen is endemic and unique to Korea. $E$. amylovora, however, exists worldwide, in Europe, the eastern Mediterranean, Pacific Asia, and North America (Bonn and Zwet, 2000). Different spatial distributions of these two Erwinia species may be attributed to differences in their physiological properties. Growth, a chief determinant of the physiological properties of the pathogens, is affected by a number of factors such as temperature, hydrogen ion concentration $(\mathrm{pH})$, salt concentration, nutrition, etc. Therefore, the growth of a location-specific pathogen, E. pyrifoliae, was investigated at various temperatures and $\mathrm{pH}$ concentrations and which was subsequently compared with that of E. amylovora, a more cosmopolitan pathogen.

In Korea, E. pyrifoliae, the causal agent of shoot blight of the Asian pear, is controlled by eradication of diseased host plants. This practice prevents multiplication and dissemination of $E$. pyrifoliae in major pear orchards. No alternative methods are currently used to control this pathogen. In the case of $E$. amylovora, chemical control combined with sanitation, pruning, eradication, and insect control have been used as methods for controlling and eliminating this pathogen. Van der Zwet and Keil (1979) summarized 
data collected on the chemical control of fire blight on apples and pears which had been published from 19201979 and found that copper compounds and antibiotics acted as effective bactericides against $E$. amylovora. Bactericides, which may be essential to the establishment of an integrated control system for reducing shoot blight incidence, have not yet been examined for their effect on the growth of $E$. pyrifoliae. In this investigation, we evaluated the sensitivity of $E$. pyrifoliae to copper sulfate, oxolinic acid, streptomycin, and tetracycline for the selection of effective bactericides against this pathogen.

\section{Materials and Methods}

Bacterial strains and culture media. The bacterial strains used in this study are listed in Table 1. The strains of $E$. pyrifoliae and $E$. amylovora were routinely grown on Mannitol Glutamic Yeast (MGY) agar plates at $28^{\circ} \mathrm{C}$ and maintained in Nutrient Broth (NA) containing 20\% glycerol at $-70^{\circ} \mathrm{C}$ (Shrestha et al., 2003). Pathogenicity and HR properties of the strains used in this study are also listed in Table 1. Pathogenicity tests on immature pear fruits, $P$. pyrifolia $\mathrm{cv}$. Singo, were performed using approximately $2 \times 10^{7}$ colony forming unit (cfu) $/ \mathrm{ml}$ of each strain as described by Shrestha et al. (2003). For HR assay, $2 \times 10^{7}$ colony forming unit $(\mathrm{cfu}) / \mathrm{ml}$ of each strain were also used and infiltrated into tobacco leaves (Nicotiana tabacum cv. Burley), as described by Shrestha et al. (2005). After infiltration, the plants were kept at room temperature and the HR was scored within $24 \mathrm{~h}$.

Table 1. List of bacterial strains used in the present study

\begin{tabular}{|c|c|c|c|c|c|}
\hline \multirow{2}{*}{ Strains $^{\mathrm{a}}$} & \multirow{2}{*}{ Host } & \multirow{2}{*}{ Location, collection date } & \multicolumn{2}{|c|}{ Characteristics } & \multirow{2}{*}{ References } \\
\hline & & & Pathogenicity & HR & \\
\hline \multicolumn{6}{|l|}{ Erwinia pyrifoliae } \\
\hline WT3 (KCCM 10283) & Pyrus pyrifolia & Jichonri, Chuncheon, Korea, 1995 & + & + & Shrestha et al. (2003) \\
\hline WT4 (KNUCPB 964) & P. pyrifolia & Jichonri, Chuncheon, Korea, 1996 & + & + & This study \\
\hline WT5 (KNUCPB 955) & P. pyrifolia & Jichonri, Chuncheon, Korea, 1995 & + & + & This study \\
\hline WT6 (KNUCPB 966) & P. pyrifolia & Jichonri, Chuncheon, Korea, 1996 & + & + & This study \\
\hline WT7 (KNUCPB 967) & P. pyrifolia & Duck Duwonri, Chuncheon, Korea, 1996 & + & + & This study \\
\hline WT8 (KNUCPB 968) & P. pyrifolia & Jichonri, Chuncheon, Korea, 1996 & + & + & This study \\
\hline WT9 (KNUCPB 989) & P. pyrifolia & Owolri, Chuncheon, Korea, 1998 & + & + & This study \\
\hline WT10 (KNUCPB 9610) & P. pyrifolia & Jichonri, Chuncheon, Korea, 1996 & + & + & This study \\
\hline WT11 (KNUCPB 9811) & P. pyrifolia & Owolri, Chuncheon, Korea, 1998 & + & + & This study \\
\hline WT15 (KNUCPB 9515) & P. pyrifolia & Jichonri, Chuncheon, Korea, 1995 & + & + & This study \\
\hline WT18 (KNUCPB 9718) & P. pyrifolia & Duck Duwonri, Chuncheon, Korea, 1997 & + & + & This study \\
\hline WT20 (KNUCPB 9520) & P. pyrifolia & Jichonri, Chuncheon, Korea, 1995 & + & + & This study \\
\hline WT24 (KNUCPB 9724) & P. pyrifolia & Owolri, Chuncheon, Korea, 1997 & + & + & This study \\
\hline WT25 (KNUCPB 9525) & P. pyrifolia & Duck Duwonri, Chuncheon, Korea, 1995 & + & + & This study \\
\hline WT30 (KNUCPB 9630) & P. pyrifolia & Jichonri, Chuncheon, Korea, 1996 & + & + & This study \\
\hline WT36 (KNUCPB 9736) & P. pyrifolia & Owolri, Chuncheon, Korea, 1997 & + & + & This study \\
\hline WT43 (KNUCPB 9743) & P. pyrifolia & Duck Duwonri, Chuncheon, Korea, 1997 & + & + & This study \\
\hline WT59 (KNUCPB 9759) & P. pyrifolia & Owolri, Chuncheon, Korea, 1997 & + & + & This study \\
\hline Epl (DSM 12162) & P. pyrifolia & Chuncheon, Korea, 1996 & + & + & Kim et al. (1999) \\
\hline Ep4 (DSM 12394) & P. pyrifolia & Chuncheon, Korea, 1997 & + & + & Kim et al. (1999) \\
\hline Ep8 (DSM 12393) & P. pyrifolia & Chuncheon, Korea, 1995 & + & + & Kim et al. (1999) \\
\hline Epl6(DSM 12163) & P. pyrifolia & Chuncheon, Korea, 1996 & + & + & Kim et al. (1999) \\
\hline \multicolumn{6}{|l|}{ E. amylovora } \\
\hline ATCC $15580^{\top}$ & P. communis & U.K. & + & + & Dye D. W. \\
\hline LMG 1877 & Cydonia oblonga & Denmark & + & + & Hockenhull J. \\
\hline LMG 1946 & P. communis & Belgium & + & + & Vantomme $\mathrm{R}$. \\
\hline LMG 2068 & Rubus idaeus, & U.S.A. & + & + & Hayward A. \\
\hline $\mathrm{Ea} 246$ & Blackberry & U.S.A. & + & + & Reis A. \\
\hline
\end{tabular}

"Type strain; ATCC, American Type Culture Centre; DSM, Deutsche Sammlung von Mikroorganism; KCCM, Korean Culture Center of Microorganisms, KNUCPB, Kangwon National University Collection of Phytopathogenic Bacteria; LMG, Laboratorium voor Microbiologie; + , positive to pathogenicity on immature pear fruit and hypersensitive response (HR) on tobacco leaves. 
Measurement of growth at different temperatures and pH. Two strains of E. pyrifoliae (WT3 and Ep16) and one strain of E. amylovora (ATCC 15580) were used to evaluate the effects of temperature and $\mathrm{pH}$ on growth. Growth at different temperatures and $\mathrm{pH}$ concentrations were automatically monitored in vitro using the turbidimetric system BioscreenC (Labsystems, Finland). To study the effects of temperature, a fresh culture of each strain was inoculated into $5 \mathrm{ml} \mathrm{MGY}$ broth and cultured for $16 \mathrm{~h}$ at $28^{\circ} \mathrm{C}$ in a shaking incubator at $160 \mathrm{rpm}$. Optical density was adjusted to 0.5 at $600 \mathrm{~nm}$ absorbance and $300 \mu \mathrm{L}$ of each strain was inoculated into honeycomb plates containing 100 cuvettes, as mentioned by Begot et al. (1996). Growth was measured every ten minutes at 3 degree intervals, ranging from $12-39^{\circ} \mathrm{C}$. As the growth of both Erwinia species was found to be the most favorable in the range of $27-30^{\circ} \mathrm{C}$, each species was again grown at 1 degree intervals at temperatures within this range.

To study the effects of acidity and alkalinity on the growth of these pathogens, MGY broth with $\mathrm{pH}$ ranging from 2.0-9.0 was prepared at intervals of 0.5 units. The growth of both Erwinia species at different $\mathrm{pH}$ concentrations was then measured using the same procedure as described for the temperature experiment. Five successive cuvettes of the same column were used for each strain in both parameters. Two cuvettes of each column were filled with the same volume of non-inoculated medium. The data were stored in the desktop computer which was interfaced with the analyzer. The individual growth curve of each inoculated cuvette was further analyzed by Excel Software (Microsoft Windows 2003) and an average of five cuvettes was taken for each strain in each parameter.

Calculation of doubling time and specific growth rates. The optimum temperature and $\mathrm{pH}$ for growth were estimated to be the values at which maximum specific growth rates of the strains were observed. The specific growth rates and doubling times were calculated from the exponential phase of growth using following formulae, as given by Pirt (1975) and Ingraham et al. (1983):

$$
\begin{aligned}
& \mathrm{M}_{1}=2 \mathrm{nM}_{0} \\
& \log \mathrm{M}_{1}=n \log 2+\log \mathrm{M}_{0} \\
& \mathrm{n}=\frac{\log \mathrm{M}_{1}-\log \mathrm{M}_{0}}{\log 2} \\
& \mathrm{k}=\frac{\mathrm{n}}{\mathrm{T}_{1}-\mathrm{T}_{0}} \\
& \mathrm{~g}=\frac{1}{\mathrm{k}}=\frac{\mathrm{T}_{1}-\mathrm{T}_{0}}{\mathrm{n}}
\end{aligned}
$$

where, $\mathrm{M}_{0}=$ initial O.D. of each strain, $\mathrm{M}_{1}=$ final O.D. of each strain, $T_{0}=$ initial time, $T_{t}=$ final time, $\mathrm{n}=$ no. of generation, $\mathrm{k}=$ growth rate constant and $\mathrm{g}=$ doubling or generation time.

Plots for the specific growth rate versus temperature and $\mathrm{pH}$ were developed to analyze the linear relationship with the growth of E. pyrifoliae and E. amylovora.

\section{Determination of Minimum Inhibitory Concentrations} (MICs). Twenty-two strains of E. pyrifoliae and five strains of $E$. amylovora were used to evaluate sensitivity to four bactericides: copper sulfate, oxolinic acid, streptomycin, and tetracycline (Table 1). MICs were determined to be the concentrations at which tested bactericides inhibited in vitro growth of theses pathogens. The MGY agar was prepared, cooled to $50^{\circ} \mathrm{C}$, and amended with filter-sterilized copper sulfate to final concentrations of $0.01,0.02,0.04,0.08$, $0.16,0.32,0.64$, and $1.2 \mathrm{mM}$; oxolinic acid to $0.001,0.002$, $0.004,0.008$, and $0.016 \mathrm{mM}$; streptomycin to $0.1,0.2,0.4$, $0.8,1.60$, and $3.20 \mathrm{mM}$; and tetracycline to $0.01,0.02,0.04$, $0.08,0.16,0.32$, and $0.64 \mathrm{mM}$. All strains were cultured overnight and O.D. was adjusted to 0.6 at $600 \mathrm{~nm}$ absorbance. $5 \mu \mathrm{L}$ of each O.D.-adjusted strain was spotted on the MGY agar plates amended with different concentrations of selected bactericides, which were then incubated at $28^{\circ} \mathrm{C}$, as described by McManus and Jones (1994). Triplicate agar plates were used for each concentration and the experiment was repeated three times. Growth was evaluated for $48 \mathrm{~h}$ at $12 \mathrm{~h}$ time intervals.

\section{Results and Discussion}

The effects of temperature and $\mathrm{pH}$ on growth rate. Specific growth rates and doubling times calculated for the strains of E. pyrifoliae and E. amylovora at monitored temperatures are given in Table 2. None of the strains grew at $39^{\circ} \mathrm{C}$. The temperature maximum for growth was estimated at $36^{\circ} \mathrm{C}$ for both Erwinia species, since, when standard physiological and biochemical tests based on Bergey's manual were performed during their identification (Shrestha et al., 2003), the strains of these pathogens did not grow at $37^{\circ} \mathrm{C}$. At maximum temperature, doubling times were calculated to be $2.69 \pm 0.10 \mathrm{~h}, 2.88 \pm 0.18 \mathrm{~h}$, and $2.72 \pm 0.06 \mathrm{~h}$ for E. pyrifoliae WT3, E. pyrifoliae Ep16, and E. amylovora ATCC15580, respectively (Table 2). Low growth rates with long doubling times were observed at 33$36^{\circ} \mathrm{C}$ (Fig. 1). The optimum temperatures for growth were observed at $27^{\circ} \mathrm{C}$ for E. pyrifoliae and $28^{\circ} \mathrm{C}$ for $E$. amylovora. At optimum temperature, doubling times were calculated to be $1.53 \pm 0.02 \mathrm{~h}, 1.50 \pm 0.04 \mathrm{~h}$, and $1.44 \pm$ $0.02 \mathrm{~h}$ for E. pyrifoliae WT3, E. pyrifoliae Ep16, and E. amylovora ATCC15580, respectively; no significant differences were observed in their growth rates (Table 2). High growth rates with short lag phases were observed for both 
Table 2. Doubling times estimated for E. pyrifoliae and $E$. amylovora at different temperatures

\begin{tabular}{|c|c|c|c|}
\hline \multirow{3}{*}{$\begin{array}{l}\text { Temperature } \\
\left({ }^{\circ} \mathrm{C}\right)\end{array}$} & \multicolumn{3}{|c|}{ Doubling time $(\mathrm{h})$} \\
\hline & \multicolumn{2}{|c|}{ E. pyrifoliae } & \multirow{2}{*}{$\frac{\text { E. amylovora }}{\text { ATCC } 15580}$} \\
\hline & WT3 & Ep16 & \\
\hline 12 & $2.89 \pm 0.18$ & $2.92 \pm 0.12$ & $4.97 \pm 0.08$ \\
\hline 15 & $2.43 \pm 0.15$ & $2.35 \pm 0.12$ & $3.84 \pm 0.12$ \\
\hline 18 & $2.20 \pm 0.07$ & $2.15 \pm 0.03$ & $2.76 \pm 0.05$ \\
\hline 21 & $1.85 \pm 0.06$ & $1.90 \pm 0.03$ & $2.16 \pm 0.05$ \\
\hline 24 & $1.62 \pm 0.04$ & $1.64 \pm 0.03$ & $1.80 \pm 0.03$ \\
\hline 27 & $1.53 \pm 0.02$ & $1.50 \pm 0.04$ & $1.49 \pm 0.03$ \\
\hline 28 & $1.53 \pm 0.04$ & $1.55 \pm 0.02$ & $1.44 \pm 0.03$ \\
\hline 29 & $1.55 \pm 0.03$ & $1.58 \pm 0.05$ & $1.48 \pm 0.02$ \\
\hline 30 & $1.61 \pm 0.03$ & $1.69 \pm 0.08$ & $1.56 \pm 0.03$ \\
\hline 33 & $1.75 \pm 0.05$ & $1.86 \pm 0.14$ & $1.65 \pm 0.04$ \\
\hline 36 & $2.69 \pm 0.10$ & $2.88 \pm 0.18$ & $2.72 \pm 0.06$ \\
\hline 39 & $4.27 \pm 0.26$ & $4.51 \pm 0.28$ & $5.11 \pm 0.25$ \\
\hline
\end{tabular}

${ }^{\mathrm{a}}$ Mean doubling time of five replicates of each strain \pm S.D.

pathogens at temperatures between 27 and $30^{\circ} \mathrm{C}$. At temperatures $\leq 21^{\circ} \mathrm{C}$, both pathogens grew slower with lower growth rates, longer doubling times, and more prolonged lag phases than those at $\geq 24^{\circ} \mathrm{C}$ (Fig. 1). However, distinct growth rates were observed at temperatures $\leq 21^{\circ} \mathrm{C}$ with doubling times of $1.85 \pm 0.06 \mathrm{~h}, 1.90 \pm 0.03 \mathrm{~h}$, and $2.16 \pm 0.05 \mathrm{~h}$ for E. pyrifoliae WT3, E. pyrifoliae Ep16, and $E$. amylovora ATCC15580, respectively. Growth rates were more distinctive at $12^{\circ} \mathrm{C}$ and showed doubling times of $2.89 \pm 0.18 \mathrm{~h}, 2.92 \pm 0.12 \mathrm{~h}$, and $4.97 \pm 0.08 \mathrm{~h}$ for $E$. pyrifoliae WT3, E. pyrifoliae Ep16, and E. amylovora ATCC15580, respectively. These results showed that $E$. pyrifoliae had higher growth rates and shorter doubling times with a prolonged lag phase at $\leq 21^{\circ} \mathrm{C}$ when compared to those of E. amylovora (Fig. 1). Based on these results, it was concluded that $E$. pyrifolice is more cold-tolerant than $E$. amylovora. Regarding the epidemic survey of shoot blight disease, E. pyrifoliae has so far been found only in the northern parts of South Korea, including Chuncheon which are much colder in winter than are the southern parts, where major pear cultivation areas are located. Although this result does not explain the reason that $E$. pyrifoliae is endemic to Korea, it can be speculated that its cold-tolerant character is one of the factors that has enabled this pathogen to survive better in the northern parts of the country than in the southern parts during the winter season.

Specific growth rates and doubling times calculated for the strains of both E. pyrifoliae and E. amylovora at different $\mathrm{pH}$ concentrations are given in Table 3 . Neither of the pathogens was able to grow at $\mathrm{pH} \leq 5.0$ and $\geq 10.0$. Low growth rates and long doubling times were observed in both pathogens at concentrations of moderately acidic

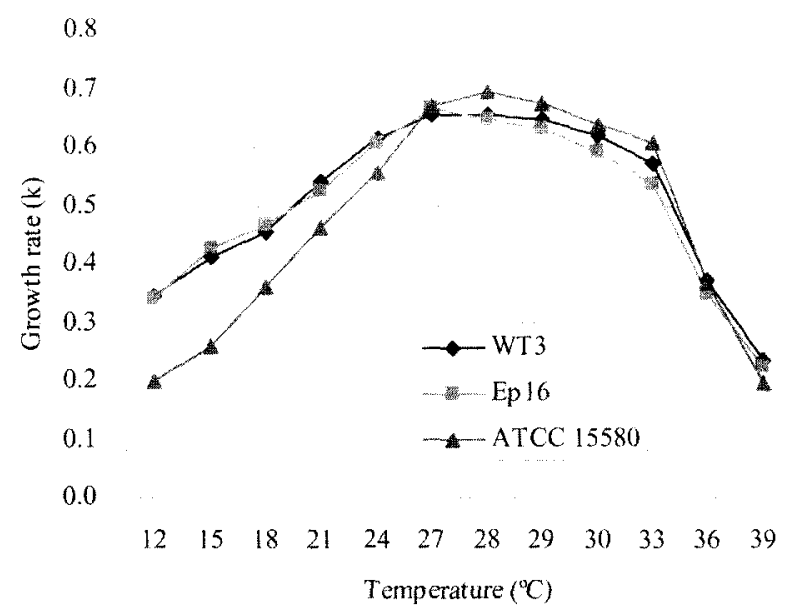

Fig. 1. Plot of the growth rates of Erwinia pyrifoliae and E. amylovora determined at different temperatures. WT3 and Ep 16 represent strains of E. pyrifoliae, whereas ATCC 15580 represents E. amylovora.

Table 3. Doubling times estimated for E. pyrifoliae and E. amylovora at different $\mathrm{pH}$

\begin{tabular}{|c|c|c|c|}
\hline \multirow{3}{*}{$\mathrm{pH}$} & \multicolumn{3}{|c|}{ Doubling time $(\mathrm{h})^{\mathrm{a}}$} \\
\hline & \multicolumn{2}{|c|}{ E. pyrifoliae } & \multirow{2}{*}{$\frac{\text { E. amylovora }}{\text { ATCC } 15580}$} \\
\hline & WT3 & Ep16 & \\
\hline 5.5 & $3.45 \pm 0.35$ & $3.22 \pm 0.13$ & $3.15 \pm 0.12$ \\
\hline 6.0 & $2.62 \pm 0.04$ & $2.82 \pm 0.11$ & $2.55 \pm 0.13$ \\
\hline 6.5 & $1.92 \pm 0.02$ & $2.12 \pm 0.03$ & $1.82 \pm 0.05$ \\
\hline 7.0 & $1.55 \pm 0.02$ & $1.56 \pm 0.02$ & $1.44 \pm 0.08$ \\
\hline 7.5 & $1.47 \pm 0.03$ & $1.49 \pm 0.08$ & $1.44 \pm 0.07$ \\
\hline 8.0 & $1.71 \pm 0.04$ & $1.75 \pm 0.03$ & $1.73 \pm 0.07$ \\
\hline 8.5 & $1.91 \pm 0.04$ & $1.89 \pm 0.08$ & $1.86 \pm 0.08$ \\
\hline 9.0 & $2.10 \pm 0.23$ & $2.07 \pm 0.18$ & $2.32 \pm 0.05$ \\
\hline 9.5 & $2.37 \pm 0.10$ & $2.51 \pm 0.10$ & $2.62 \pm 0.04$ \\
\hline
\end{tabular}

${ }^{a}$ Mean doubling time of five replicates of each strain \pm S.D.

$\mathrm{pH}$ (5.5-6.5) and alkaline $\mathrm{pH}$ (8.5-10). At pH 5.5, doubling times were calculated to be $3.45 \pm 0.35 \mathrm{~h}, 3.22 \pm 0.13 \mathrm{~h}$, and $3.15 \pm 0.12 \mathrm{~h}$ for E. pyrifoliae WT3, E. pyrifoliae Ep 16, and E. amylovora ATCC15580, respectively (Table 3). Similarly, doubling times of $2.37 \pm 0.10 \mathrm{~h}, 2.51 \pm 0.10 \mathrm{~h}$, and $2.62 \pm 0.04 \mathrm{~h}$ for E. pyrifoliae WT3, E. pyrifoliae Ep16, and E. amylovora ATCC15580, respectively, were calculated at $\mathrm{pH}$ 10.0. The most favorable $\mathrm{pH}$ was found at 7.5 for both pathogens, which showed optimum growth with short doubling times of $1.47 \pm 0.03 \mathrm{~h}, 1.49 \pm 0.08 \mathrm{~h}$, and $1.44 \pm 0.07$ h in E. pyrifoliae WT3, E. pyrifoliae Ep16, and E. amylovora ATCC 15580, respectively (Table 3, Fig. 2). These results showed similar effects of $\mathrm{pH}$ on the growth of these two pathogens, although some variation was observed between acidic (pH 5.5-6.0) and alkaline conditions (9.09.5) (Table 3). 


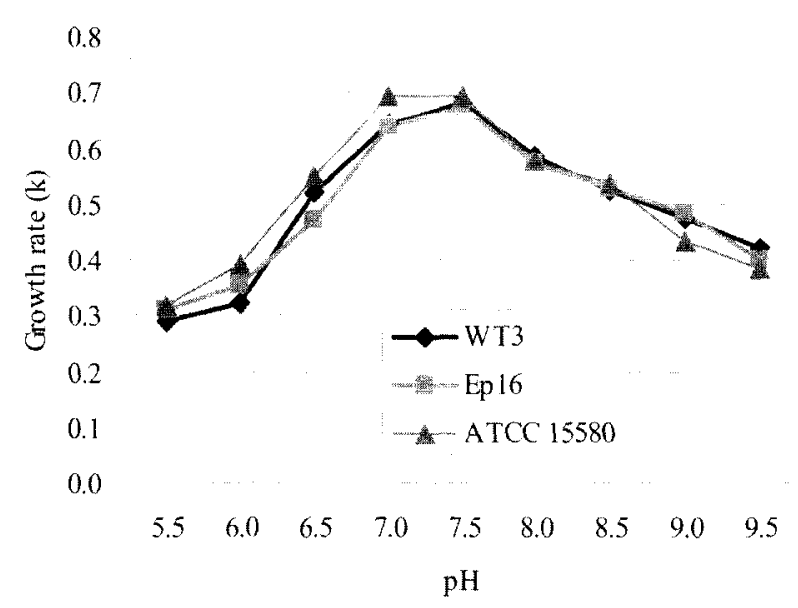

Fig. 2. Plot of the growth rates of Erwinia pyrifoliae and $E$. amylovora determined at different $\mathrm{pH}$. WT3 and Epl6 represent strains of $E$. pyrifoliae, whereas ATCC 15580 represents $E$. amylovora.

Copper sulfate, oxolinic acid, streptomycin, and tetracycline sensitivity. MICs of copper sulfate, oxolinic acid, streptomycin, and tetracycline were estimated for the strains of both $E$. pyrifoliae and E. amylovora. All strains of both pathogens were capable of growing in the presence of $\leq 0.08 \mathrm{mM}$ copper sulfate. Eight strains (WT5, WT6, WT7, WT15, WT20, WT36, WT47, and WT59) of E. pyrifoliae and two strains (LMG 1877 and Ea246) of E. amylovora further grew in concentrations of up to $0.32 \mathrm{mM}$ copper sulfate, which indicates variation in their sensitivity to this bactericide. However, none of the strains of $E$. pyrifoliae and $E$. amylovora were capable of growing in the presence of oxolinic acid, streptomycin, or tetracycline. MICs of $0.001 \mathrm{mM}, 0.1 \mathrm{mM}$, and $0.01 \mathrm{mM}$ were determined for oxolinic acid, streptomycin, and tetracycline, respectively, showing their sensitivity to all tested bactericides. These findings suggest that tested bactericides can be used as a part of integrated pest management to control E. pyrifoliae, along with eradication of diseased plants, the only method used currently in Korea for control of E. pyrifoliae.

\section{References}

Ark, P. A. 1937. Variability in the fire blight organism, Erwinia amylovora. Phytopathology 27:1-28.

Beer, S. V., Kim, J. H., Zumoff, C. H., Bogdanove, A. J., Laby, R. J., Gustafson, H. L., Momol, T., Aldwinckle, H. S., Tanii, A. and Tamura, O. 1996. Characterization of bacteria that cause "bacterial shoot blight of pear" in Japan. Acta Hortic. 411:179181.

Begot, C., Desnier, I., Daudin, J. D., Labadie, J. C. and Lebert, A. 1996. Recommendations for calculating growth parameters by optical density measurements. J. Microbiol. Methods 25:225232.
Billing, E. 1974. The effect of temperature on the growth of the fire blight pathogen, Erwinia amylovora. J. Appl. Bacteriol. 37:643-648.

Billing, E., Baker, L. A. E., Crosse, J. E. and Garrett, C. M. E. 1961. Characteristics of English isolates of Erwinia amylovora. J. Appl. Bacteriol. 24:195-211.

Bonn, W. G. and Van der Zwet, T. 2000. Distribution and economic importance of fire blight. In Vanneste J. L (ed), Fire blight: The disease and its causative agent, Erwinia amylovora. CABI publishing, UK, pp 37-53.

Ingraham, J. L., Maloe, O. and Neidhardt, F. C. 1983. Growth of bacterial cell. Sinauer Associates Inc. Massachusetts, USA.

Jock, S., Jacob, T., Kim, W.-S., Hilgebrand, M., Vosberg, H. P. and Geider, K. 2003. Instability of short-sequence DNA repeats of pear pathogenic Erwinia strains from Japan and Erwinia amylovora fruit tree and raspberry strains. Mol. Genet. Genomics 268:739-749.

Kim, W.-S., Gardan, L., Rhim, S. L. and Geider, K. 1999. Erwinia pyrifoliae sp. nov., a noval pathogen affecting Asian pear trees (Pyrus pyrifoliae Nakai). Intl. J. Sys. Bacteriol. 49:899-906.

Kim, W.-S., Jock, S., Paulin, J. P., Rhim, S.-L. and Geider, K. 2001. Molecular detection and differentiation of Erwinia pyrifoliae and Host range analysis of the Asian pear pathogen. Plant Dis. 85:1183-1188.

Maxson-Stein, K., McGhee, G. C., Smith, J. J., Jones, A. L. and Sudin, G. W. 2003. Genetic analysis of a pathogenic Erwinia sp. isolated from pear in Japan. Phytopathology 93:1393-1399.

Mc Manus, P. S., and Jones, A. L. 1994. Epidemiology and genetic analysis of streptomycin-resistant Erwinia amylovora from Michigan and evaluation of oxytetracycline for control. Phytopathology. 84:627-633.

Mizuno, A., Sato, S., Kaeai, A. and Nishiyama, K. 2000. Taxonomic position of the causal pathogen of bacterial shoot blight of pear. J. Gen. Plant. Pathol, 66:48-58.

Pirt, S. J. 1975. Principles of microbe and cell cultivation. Blackwell, Oxford, UK.

Rhim, S.-L., Voelkisch, B., Gardan, L., Paulin, J. P., Langlotz, C., Kim, W.-S. and Geider, K. 1999. An Erwinia species, different from E. amylovora cause a necrotic disease of Asian pear trees. Plant Pathol. 48:514-520.

Shrestha, R., Koo, J. H., Park, D. H., Hwang, I., Hur, J. H. and Lim, C. K. 2003. Erwinia pyrifoliae, a causal endemic pathogen of shoot blight of Asian pear tree in Korea. Plant Pathol. J. 19:204-300.

Shrestha, R., Tsuchiya, K., Baek, S. J., Bae, H. N., Hwang, I., Hur, J. H. and Lim, C. K. 2005. Identification of $d s p E F$, hrpW, and $h r p N$ loci and characterization of the $h r p N_{E p}$ gene in Erwinia pyrifoliae. J. Gen. Plant Pathol. 71 (in press).

Young, J. M., Leuketina, R. C. and Marshal, A. M. 1977. The effects on temperature on growth in vitro of Pseudomonas syringae and Xanthomonas pruni. J. Appl. Bacteriol. 42:345354.

Van der Zwet, T. and Keil, H. L. 1979. Fire blight - A bacterial disease of rosaceous plants. United States Department of Agriculture Handbook 510, Washington DC, USA. 